\title{
ECOLOGICAL MARKETING PRACTICE AND ISSUES OF AGRICULTURAL ECONOMIC SUSTAINABILITY: A FOCUS ON OIL FIRMS' ACTIVITIES IN NIGER DELTA
}

\author{
Komene Goodnews Loanyie (Ph.D) ${ }^{1}$ and Nweidua Lebia Patricia (Ph.D) ${ }^{2}$ \\ Ignatus Ajuru University of Education, Department of Marketing, Faculty of Business \\ Studies, Port Harcourt Rivers State Nigeria. \\ ${ }^{1}$ komenegoodnews@gmail.com \\ 2nukania@gmail.com
}

Cite this article:

Komene G.L., Nweidua L.P. (2021), Ecological Marketing Practice and Issues of Agricultural Economic Sustainability: A Focus on Oil Firms' Activities in Niger Delta. British Journal of Management and Marketing Studies 4(4), 99-128. DOI: 10.52589/BJMMSYGBKCLUR.

\section{Manuscript History \\ Received: 7 Dec 2021 \\ Accepted: 21 Dec 2021 \\ Published: 30 Dec 2021}

Copyright $\odot 2020$ The Author(s). This is an Open Access article distributed under the terms of Creative Commons AttributionNonCommercial-NoDerivatives 4.0 International (CC BY-NC-ND 4.0), which permits anyone to share, use, reproduce and redistribute in any medium, provided the original author and source are credited.
ABSTRACT: This study was carried out to examine the extent to which the ecological marketing practice of the oil firms: Shell BP, Agip Oil Company, and Elf Oil Company have improved agricultural economic wellbeing of the oil-bearing communities in Niger Delta. A descriptive survey research design was employed in this study. The population of the study was 37,965,391 drawn from Niger Delta States based on which a sample size of 400 respondents was determined using Taro Yamane's sample size determination techniques at 0.5 percent level of significance. The purposive sampling procedure was employed to enable the researcher to select the representative sample elements of the population interest from the right respondents who have adequate knowledge of the study under investigation from the different strata that makes up the population of the study. A structured instrument for data collection containing twenty (20) item questions was used for the study. The face and content validation of the instrument was obtained through the judgment of experts. A test-retest method was used to determine the reliability of the instrument and the reliability index of .83 was obtained. The data collected for the study were analyzed using the mean score test and the percentage test method to answered the research questions; while the inferential statistics of the Z-score test was used to test the null hypothesis at .05 level of significance. Results obtained revealed that "Ecological marketing practice of the oil firms does not significantly improved agricultural economic poverty, agricultural market failure, agricultural economic frustration, and agricultural land limitation in the oil-bearing communities in Niger Delta". The implication of this finding is that the oil firms' ecological sustainability marketing activities was considered to lack the needed proactive improvement values which, if ethical based ecological effort is not adopted to create sustainable improvement; oil firms might experience unpredicted operational interruption by the oil-bearing communities. It was therefore, recommended that oil firms should consider employing proactive ecological marketing efforts in a more ethical and responsible manner to sustain the agricultural economic wellbeing of the oil-bearing communities.

KEYWORDS: Ecological Marketing Practice, AgriculturalEconomic Sustainability, and Oil Firms. 


\section{INTRODUCTION}

The ecological marketing practice of the oil firms is driven by its engagement in the marketing activities of protecting, improving, sustaining and preserving the ecological system to satisfy consumers' needs and the wellbeing of the society, could be considered as the ecological marketing practice of the oil firms. In view of this, the activities of oil production is strongly connected with the oil firms' ecological marketing practice, which appears to have over looked the value of agricultural economic sustainability with incessant oil pollution in Niger Delta. The state of the incessant oil pollution is therefore, associated with the production activities of the oil firms that destroy the flora and fauna which are elements of the ecosystem. Relatively, the marketing intention and activities of protecting, improving, sustaining and preserving the wellbeing of the ecological system, is the oil firms' ecological marketing practice.

Without doubt, the fast growing need for environmental protection and sustainability of the ecosystem has in the recent time calls for the need to improve, protect, and sustain the ecological wellbeing of the environment from the seeming uncontrolled increase in the level of oil pollution generated by the multinational oil firms. This becomes more realistic in Niger Delta where cases of incessant oil spills and gas flaring activities appear endless. The need for efficient practice of ecological sustainability marketing by the oil multinational firms becomes necessary in Niger Delta. The evidence of inefficient practice of ecological sustainability marketing by the multinational oil firms were traced to gross neglect of societal marketing values which ecological sustainability marketing is an extension. In condemnation of such unethical ecological sustainability marketing practice, the attention of environmental protection agencies, such as, the Sierra Clubs, Friends of the Earth, the Green Peace and the World Health Organization was attracted.

Having noticed the growing increase in the poor ecological sustainability marketing activities of the oil multinational firms, Ukaogo (2007) explained that ecological sustainability marketing is a marketing practice that focuses on the green marketing intention of protecting, sustaining, improving and preserving environmental values in any given society. In line with this, oil pollution hazard is refers to as the harmful chemical substances generated from oil spills and gas flaming activities of oil exploration firms that poisons the air, land and water (Danhagu, 2008). This add meaning to the opinion that the concern of individuals, organizations and the government to protect, sustain, preserve and improve the green value or benefits of the environment is more of environmental marketing concern in the society.

Similarly, the economic wellbeing of the host oil-bearing communities were not treated with care by the oil-firms for their failure to understand that, "business exist at the discretion of consumers, and the society; and it is mainly by satisfying the consumer citizens and the society that business firms and our economic system can justify its true existence and hope to keep operating; for few dishonest and unethical business managers have done a great deal of environmental damage; before consumer citizens noticed to take the necessary steps to stop their harmful operations (Perreault and McCarthy, 1999).

In line with this reality, novel researchers in the recent time observed that there are contrary unsustainable ecological marketing practice, which on noticing the activities of the oil firms, Hicks and Gullets(1980) asserts that unethical managers has exerted some poor managerial influence on the management of their surrounding for selfish reasons of making huge profit 
at the determent of the consumer citizens that give the company the succor to operate. The concern of the oil firms appears not to be protection oriented based its sluggish attempt to sustain the agricultural economic wellbeing of the oil-bearing communities.

In addition, evidence of oil pollution hazard result from unsustainable ecological marketing practices has poisoned the economic wellbeing of the locals with high density of hydrocarbon substances on their safe drinking water, fertile land quality, air through gas flaring activities and incessant oil spillages. This implies that oil firms in Niger Delta have not understood the implication in the reality that: "Business organizations must be involved in improving the general quality of life in the society, and solve social economic problems of the host community that give firms the succor to operate. It is therefore, the key function of a business organization to ensure successful performance when the firm cares for the wellbeing of the consumer citizens its production activities. Thus, business practice and the sustainability of the business existence in the society is a function of ecological sustainability marketing activities of the corporate citizen that gives serious concern to the protection of ecological needs in the society (Danhagu, 2008).

Having observed the economic threats resulted from what seems to be the failure of the oil firms' ecological sustainability marketing practices, it was still doubtful to notice that "At this age of environmental deterioration, neglect of social services, resource shortages, explosive population growth; World hunger and poverty, and the increase in environmental awareness;" the multinational oil firms, such as, Agip Oil Company, Shell BP, and Elf Oil Company still seems to be busy imposing expensive economic threats on the agricultural productivity in the host oil-bearing communities in Niger Delta".

It is against this background that this study seeks to find out the extent to which the ecological sustainability marketing activities of the oil firms: Shell BP, Agip Oil Company, and Elf Oil Company have improved the quality of agricultural economic wellbeing of the oil-bearing communities in Niger Delta.

\section{Statement of the Problem}

The reality concerning the increasing effects of oil pollution hazards caused by the multinational oil firms were traceable to high density of incessant oil spills and gas flaring activities of the oil firms that effects safe drinking water, marine lives, land vegetations, and quality air in the oil-bearing communities. This was not different from ecological issues in Niger Delta caused by oil pollution generated by the multinational oil firms. On a large scale, the impact of the hydrocarbon substances released by the oil firms on the land has distorted the economic health condition of the locals. Eating of contaminated agricultural food produced in the oil-bearing communities has also caused various forms of oil related sicknesses that exploit the financial economic wellbeing of the people; which resulted in compounded health cost of treating the ailments. As if this was not enough, the issue of whether quality assurance in the security of the ecological system was could be obtained for agricultural economic means of livelihood appears to be an uphill task in Niger Delta. In view of this, the destruction of the flora and fauna with severe oil spills and gas flaring activities of the oil firms seems not to have an end in Niger Delta following the findings in Funiwa(2002) who opined that the destruction of the ecological system in Nigeria has not ceased and the oil firms' sustainability marketing has been marked with great failures as 
considered to lack socio-economic value to sustain the health and economic condition of living and non-living things.

On a large scale, the increasing cost of treating oil polluted agricultural food ailment associated with unhealthy food production has result in huge financial frustration which does not only caused unwanted health hypertension among the people traceable to the destruction of the economic source of livelihood. However, this was noticed to have generated retrogressive oil pollution impact on the long-life span of the host oil-bearing communities; thereby, causing high rate of immorality associated with poor quality assurance in the protection and sustainability of ecological values in oil-bearing communities. Also, for the purpose of discouraging the increase reports of oil pollution activities of the oil firms, the World Health Organization, Friends of the Earth, The Green People, Nigeria Environmental Protection Agency, the Sierra Club and the Host Oil-Bearing Communities in strong term condemned the environmental marketing activities of the oil firms in Niger Delta, specifically Rivers State; but little or no significant improvement has been done to avoid the oil pollution hazards (Morgan and Ruggurg, 2000; and Funiwa, 2002).

Having noticed the seeming endless negative impact of the observed ecological sustainability marketing activities and practices of the oil firms in Niger Delta, it becomes expedient for this study to find out if, the ecological sustainability marketing activities of oil firms: Shell BP, Agip Oil Company, and Elf Oil Company has significantly, improved the quality of agricultural economic wellbeing of the oil-bearing communities in Niger Delta.

\section{Aim and Objectives of the Study}

The main objective of this study is to examine the extent to which the oil firms' ecological marketing practice has sustained the agricultural economic wellbeing of the oil-bearing communities in Niger Delta. In order to achieve this aim, the following specific objectives were considered.

i. To examine the extent to which the ecological marketing practice of the oil firms has reduced the trend of agricultural economic poverty in oil-bearing communities in Niger Delta.

ii. To examine the extent to which the ecological marketing practice of the oil firms has reduced the trend of agricultural market failure in oil-bearing communities in Niger Delta.

iii. To examine the extent to which the ecological marketing practice of the oil firms has prevented agricultural economic frustration in oil-bearing communities in Niger Delta.

iv. To examine the extent to which the ecological marketing practice of the oil firms has prevented agricultural land limitation in oil-bearing communities in Niger Delta. 


\section{Research Questions}

The following research questions are used as guide in this study.

(i) To what extent does the ecological marketing practice of the oil firms, reduced the trend of agricultural economic poverty in the oil-bearing communities in Niger Delta?

(ii) To what extent does the ecological marketing practice of the oil firms, reduced the trend of agricultural market failure in oil-bearing communities in Niger Delta?

(iii) To what extent does the ecological marketing practice of the oil firms, prevents agricultural economic frustration in oil-bearing communities in Niger Delta?

(iv) To what extent does the ecological marketing practice of the oil firms, prevents agricultural land limitation in oil-bearing communities in Niger Delta?

\section{Research Hypothesis}

The following research hypotheses were used in this study. However, they are stated in null form.

Ho1 The ecological marketing practice of the oil firms, has not significantly reduced the trend of agricultural economic poverty in the oil-bearing communities in Niger Delta.

$\mathbf{H}_{\mathbf{O} 2}$ The ecological marketing practice of the oil firms, has not significantly reduced the trend of agricultural market failure in oil-bearing communities in Niger Delta.

$H_{03}$ The ecological marketing practice of the oil firms, has not significantly prevented agricultural economic frustration in oil-bearing communities in Niger Delta.

$\mathbf{H}_{\mathbf{O} 4}$ The ecological marketing practice of the oil firms, has not significantly prevented agricultural land limitation in oil-bearing communities in Niger Delta.

\section{CONCEPTUAL FRAMEWORK}

\section{Conceptual View of Ecological Sustainability Marketing of Agricultural Economic Quality Assurance}

Ecological sustainability marketing view of agricultural economic quality assurance is traced to the sustainable marketing practice of a business organization that seeks to protect, preserve and improve the socio-economic wellbeing of its consumers and the environment. As for oil firms, ecological sustainability marketing activities is design to maintain a green view of agricultural economic quality in an environment. This implies that agricultural economic quality assurance provided by oil firms is a function of ecological sustainability marketing practice that focuses on the avoidance of oil spillage and gas flaring activities. Ecological sustainability marketing is the marketing practice that deal with the application of ethical and responsible marketing focused on the protection, sustainability, improvement and preservation of ecological system (Funiwa,2002). Ecological sustainability marketing benefits and values to living and non-living things is therefore determined by the level of quality economic assurance generated from business organizations' production activities 
Ekpu, (2010), adds that oil firms has rendered the ecosystem useless and the agricultural production of healthy food and marine lives has died unnaturally. This related the concept of ecological sustainability marketing with the concern of societal marketers who seeks to ensure complete avoidance of oil pollution hazards on land and water. The agricultural economic oriented protection mentality concerning the negative impact of oil pollution is an ecological sustainability marketing concern for agricultural economic security. Ecological sustainability marketing concept therefore, holds that "Marketers and business organizations should search for ecological needs of the society and adopt the green approach to satisfy them effectively and efficiently.

Morgan and Ruggurg (2000), further contended that ecological sustainability marketing concept is a facet or element of societal marketing from which the ecological and green marketing practice are deduced. Conceptually, societal marketers view ecological sustainability as an integration of both ecological and green marketing practice based on which the fauna and flora are protected, sustained, improved and preserved for the wellbeing of the consumer citizens in the oil-bearing community. Ecological sustainability marketing activities and issues of agricultural economic quality assurance in oil-bearing community is thus, a function of agricultural production in Niger Delta.

\section{Conceptual View of Agricultural Economic Sustainability Concerning Oil Firms}

The ecological sustainability marketing activities anchors on the idea of sustaining the agricultural economic wellbeing of the oil-bearing community. The driven value of ecological marketing on agricultural economic sustainability in Niger Delta is practically connected with the extent of oil pollution effects on the ecological system. On this note, oil pollution could be defined as the harmful discharge of toxic petroleum substances, which poisons the agricultural economic source of livelihood of the people when oil production is not guided by ethical marketing principles (Ukaogo, 2007). It is therefore not out of context to understand that oil pollution has no positive relationship with ecological sustainability marketing activities. Oil pollution is thus, defined as the poisonous petroleum hydrocarbon substances released into environment that affect the economic wellbeing of the people, plants, fish, birds, animals, land, air and water (the flora and fauna) as constituents of the ecosystem (Danhagu, 2008). It is therefore, a natural phenomenon that a safe land, waters and air are not gifts from our parents, but a debt we owe to pay back to our children in good health without leaving its harmful future effects on them (Funiwa,2002).

On this note, the economic consideration of ecological sustainability marketing activities is disconnected from oil pollution hazard that promote harmful impact on fertile agricultural land. Heig (1999) adds that ineffective ecological sustainability marketing practice of the oil firms in oil bearing communities has caused a great deal of harm to the wellbeing of the environment, the ecosystem and the society. This add meaning to the view in Ekpu (2010) who explain that ecological sustainability marketing concern of the oil firms is to ensure proper prevention of oil pollution that enhanced human existence and environmental value. This was not out of context in the reality "firms have only one job; and that is to give customers exactly what they want, when they want it, and where they want it (Perreault and McCarthy, 1999)". The contrary negative activities of oil producing firms not to give the oilbearing communities what they want and how they want it, was not considered different from the environmental reality in Niger Delta. 
To justify this, Bomi (2010) relates that result oriented environmental management activities of oil firms is the management concern to improve the firms' ecological sustainability marketing activities design to avoid the danger of oil production impact on human life and the ecosystem. In line with this, Fayifu (2006).opined that the aim to protect, improve and sustain human life from the harmful effects of environmental pollution hazards is the conscious efforts ecological sustainability marketers. Thus, Williams (2000) maintains that ecological sustainability marketing is driven by environmental oriented consciousness to protect, preserve and sustain the agricultural economic value of the flora and fauna. This confirms the reality that "Successful marketers define their target markets in terms of the needs they are trying to satisfy rather than the product they sell (Eze and Ozo, 2005)".

\section{Ecological Marketing Practice of the Oil Firms and Reduction in the Trend of Agricultural Economic Poverty in Oil-Bearing Communities in Niger Delta}

The ecological marketing practice of reducing the trend of agricultural economic poverty in the oil-bearing community by the multinational oil firms appears to have indicated sign of severe failure caused by ineffective ecological marketing consideration. This was not out of context in the view that harmful oil pollution in Niger Delta has damaged the ecosystem. Right from 1958 precisely, when Shell BP as an oil firm started its operation in Ogoni land; oil spills explosion that causes some dangerous toxic substances on the farm-lands and water bodies containing hydrocarbons, acidic chemicals, inorganic metals, such as mercury or arsenic flammable solvents, pesticides, herbicides phenols and explosive among others, have destroyed the green value of the land. This was not out of context in the view that the oil firms' ecological marketing practice has not proactively deduced the trend of agricultural economic poverty in Niger Delta.

Similarly, the poor practice of ecological marketing by the oil firms in Niger Delta, when embarking on oil production activity has destroy the sustainability of agricultural-economic source of livelihood of the locals in oil-bearing communities. This implies that the petroleum resource that sustained the economy of Nigeria and destroys the agricultural economic wellbeing of farmers and fishermen in oil-bearing communities has being extremely harmful and frustrating to human existence in the oil-bearing locality (Asakitikpi and Oyelavan, 2006). For this and similar reasons, point out that "Some business organizations have lost their ethical values and mutual relationship with their host communities for failure of being socially responsible and ethical in attending to social needs and problems of the host communities (Omuni and Ekan, 2012)”.

The rhetoric question about whether oil firms in Niger Delta is actually practicing ecological sustainability marketing was a major concern of the oil firms in the recent time to satisfy the agricultural economic and health needs of the consumer citizens. In response to this rhetoric question, Fayifu (2006) relates that the outcome of oil firms' exploration activities that promotes environmental degradation, socio-economic frustration and economic hardship that cause potential threats to the host communities' main source of livelihood was not only harmful but unsustainable. This tends to confirm that the economic wellbeing of the oilbearing community was not ethically considered in the ecological sustainability marketing activities of the oil firm by avoiding oil pollution in oil-bearing communities. No wonder Ekpu (2010) observes that we witnessed the slow poisoning of the waters of this country and the destruction of vegetations and agricultural lands with oil spills that occur during petroleum operations. Having observed this fast growing trend of endless poisoning of the 
waters, air and land in Niger Delta, it was significant to ascertain the extent to which oil firms' ecological sustainability marketing activities has improved the agricultural economic poverty of the oil-bearing communities. In response to this, Bomi (2010) relates that oil companies in Niger Delta has being unhealthy and unethical in their oil production activities towards agricultural economic wellbeing of the locals who suffers the effects and defects of oil pollution benefits caused by the firms' gross neglect to practice proactive ecological sustainability marketing. In view of this, Williams (2000), opined that the welfare of nonhumans is intrinsically valuable and morally assessed for protection, preservation, respect and sustainability by the natural man in the society.

Having noticed the immediate huge profit intention of the multinational oil firms and their uncaring attitude showing lack of interest in the socio-economic wellbeing of the oil-bearing communities, Kotler (2000), advised that "It is more important and necessary to do what is strategically right than what is immediately profitable; for it is no longer enough to satisfy customers, you must delight them". In order to add meaning to this, Frank Hungal, an American executive, states also that "My firm serves the target market for they make the firm to serve; and the firm cannot survive and exist without them (Schiffman and Kanuk 2009)". This implies that the survival and existence of oil firms rest primarily on the oasis and succor of the oil-bearing community. Therefore, it is not out of place for oil firms to protect and sustain the host communities' interests.

This add meaning to the view that ecological sustainability marketing activities of the oil firms appears not to have been economically healthy to sustain the agricultural economic wellbeing of the locals in oil-bearing communities, but posed more destructive oil spills impact on their means of livelihood.. To give reason for this, Fayifu (2006), observes that the destruction of the biota, micro flora and fauna that form the foundation base of food chain were caused by oil spills and the effects of gas flaring activities of oil firms. This implies that the ecological sustainability marketing activities of the oil firms were unsustainable, driven with unwanted harmful impact of petroleum chemical substances that poisons fertile land, and cause stagnant agricultural productivity, food insecurity, poor crops yields and unproductive harvest; as well as rendering the protein-us marine source hazardous (Bomi, 2010).

\section{Ecological Marketing Practice of the Oil Firms and Reduction in the trend of Agricultural Market Failure in Oil-Bearing Communities in Niger Delta}

From the economic perspective of agricultural market failure in Niger Delta, it was observed that oil pollution caused by the oil firms has constitutes a type of market failure that resulted in inefficient practice of ecological marketing practice; which does not seeks to sustain the agricultural economic wellbeing of the locals. Thus, this failure model is used to analyze ecological sustainability marketing problems that are caused by oil firms to distort productive agricultural yields. This is becomes a failure model which typifies that oil firms has engaged in oil spills and gas flaring activities with selfish profit motive that destroys farmlands and marine lives with harmful petroleum substances that leads to agricultural market failure.

Similarly, gas flaring activities of the oil firms which caused global warming and acid rain that destroys the land, crops and other valued vegetations in Niger Delta has to a large extent constitute grave agricultural market failure. Without doubt, the situation has resulted in poor agricultural yields and economic hardship that create agricultural market failure, which posed 
long-term economic threats on the economic source of livelihood of the people. On this note, Aakol (2009), affirms that the fear of food insecurity and economic frustration caused by oil pollution has generated more serious threats of agricultural market failure to the economic survival of residents in the oil-bearing communities in Niger Delta where its resultant hypertension and short life span of the farmers and fishermen becomes a factor of reality in poor practice of ecological sustainability marketing.

According to Ekpu (2010) the end result of the oil firms' ecological sustainability marketing activities associated with oil spills and gas flaring activities has created long term dissatisfaction and lack of interest among members of the host community towards the production activities of the oil firms. For this reason, Osabie (2007), argued that poor environmental marketing activities of the oil firm, is the same as the poor ecological marketing activities of the firm; showing its inability to sustain the environmental ecological values in oil polluted communities. This implies that the oil firms' failure to consider the practice of its ecological marketing effective and sustainable might cause its objectives threatened by the consumer citizens who seeks to protect the ecological value of their environment.

For this and similar reasons, Briggs (2007), puts that business organizations that fails to recognize the need to protect its environment should be made responsible to recognize the values of ecological based sustainability marketing to the wellbeing of farmers and fishermen in the host community. In line with this, Ideudia and Ite (2007), opined that production oriented marketing firms need to work hard and smarter at looking for best ways to satisfy consumers' needs without sacrificing the current and future environment of the host stakeholders; for firms that are not environmentally conscious are already paying billions of dollars to correct environmental problems that were created years ago.

To justify this, research report in the punch news paper proved that the pollution of farmlands with spills containing hydrocarbons, over the years has led to poor farm yields that caused severe poverty in oil-producing communities in Niger Delta (Punch, July 10, 2005). With these unwanted irregularities observed in the oil firms' ecological sustainability marketing activities, Kotler (2000) observed that "the market is growing so fast that the companies no longer worry about best ways of satisfying its customers and their wellbeing". The economic wellbeing of host stakeholders no longer appears significant in the production activities of oil firms. Therefore, despite the devastating effects of hydrocarbon pollutions on the traditional means of livelihood of the people, it was still observed that oil spills and gas flaring impact has come to be an inevitable, tolerated and acceptable aspect of oil production process in Nigeria (Osaghae, 2007).

Without doubt, oil pollution has generated stagnant agricultural production, food insecurity, poor crops yields and unproductive harvest; caused by the oil firms and this has resulted in unemployment, expansion of poverty rate in rural and urban areas among farmers and distributors of farm yields within the age of 39 years and above (Tuyizere , 2007). On a large scale, oil firms' ecological sustainability marketing activities has not only resulted in poor use of land decision and resources but end up posing agricultural market failure, economic hardship and poverty among the people. The state of ecological sustainability marketing activities and agricultural market failure associated with economic hardship has extended to mass retrogression in the educational progress of children whose personal rights to their source of livelihood was marginalized and exploited with oil pollution. For this reason, 
Briggs (2007), submitted that to the Niger Delta people, oil boom has being a doom and years of official neglect, epitomize by hunger, poverty and injustice that hinged on regional denial of productive health and agricultural yields.

In consideration of the trend in agricultural market failure, Bomi (2010), confirmed that the available land space in the oil-producing states for agricultural production in Niger Delta has been negotiated with foreign based oil companies by the government for oil exploration, while the left-over for agricultural activities are threatened by the effects of oil spills and gas flaring activities. In view of this, Perreaut and McCarthy (1999) states that marketers ought to give careful attention to environmental issues, for few dishonest or unethical managers has done a great deal of damage to the environment before the consumer citizens takes the necessary steps to stop them. It is therefore observed that, with evidence of incessant oil pollution in Niger Delta, oil firms' ecological sustainability marketing activities still appear to lack merit of value to sustain, preserve and improve agricultural economic situation of the people in a bid to prevent agricultural market failure in the oil-bearing communities.

\section{Ecological Marketing Practice of the Oil Firms and Reduction in the Trend of Agricultural Economic Frustration in Oil-Bearing Communities in Niger Delta}

The practice of ecological marketing to avoid agricultural economic frustration was traced to the avoidance of the released of sulfur oxide and nitrogen oxides that forms acid rain, which resulted in the destruction of fruitful soil productiveness, associated with poor growth of trees, grasses, and other vegetations, which has been extremely unethical and inhuman on the part of the oil firms by their oil production activities. It is therefore, cogent enough to understand that ecological marketing is driven by ethical marketing intention to sustain and improve the environmental ecological wellbeing of the locals. Thus, the resultant effect of "unethical ecological marketing activities of oil firms" is the same as "unsustainable ecological marketing activities of the oil firms" to protect and improve the ecological value of the environment in a sustainable manner that will guide against agricultural economic frustration (Omuni and Ekan, 2012).

On a large scale, this will contributed to the fast growing reduction in the harmful impact of oil pollution on agricultural production in the oil-bearing community on an extensive scale (Okoh, 2009). Also, the impact of oil pollution on agricultural yields has inflicted economic set back on farmers, fishermen, hunters and timber producers among others in the oil-bearing communities in Niger Delta. Indeed, the situation has to large extent, resulted in food insecurity that forms obstacles to the agricultural productivity in the host communities (Onuoha, 2008). Hence, Uba (2002), opined that severe poverty, associated with economic frustrations has become the daily life portion of people living in the oil-bearing communities in Niger Delta. The oil exploration activities of oil firms in Niger Delta was a confirmation of the fact that some business organizations have lost their ethical values and mutual relationship with the host society for failure of being socially responsible to social problems and needs of the host communities (Omuni and Ekan, 2012).

Significantly, if a business firm by its ecological sustainability marketing activities fails to recognize the relationship between its consumers and the ecological systems in the environment, the wellbeing of the firm will be threatened by members of the society (Osaghae, 2007). Similarly, this situation does not give the host community the opportunity to be identified by their socio-economic activity. To this end, Tuyizere (2007) opined that oil 
activities in Niger Delta has made its natural wealth to become its main source of poverty, misery and unwanted sorrow that rendered the productive population jobless by alienating the host community from their meaningful farming and fishing activities. Research reports has creditably pointed out that oil spills and gas flared have made life extremely difficult for people in oil producing communities whose sources of livelihood are mainly farming and fishing (Okoh, 2009). To confirm the truth of this report, it was revealed that the pollution of farmlands with oil spillage substances and hydrocarbons over the years have led to poor farm yields and poverty in oil-producing communities of Niger Delta (Punch, July 10, 2005). For this and similar reasons, Kotler (2000) opines that the future is no longer ahead of us; it has already happened based on the existing activities. This explains that the frustration in the socio-economic future wellbeing of the oil-bearing communities in Niger Delta is no longer ahead, but rather it is determined now by the outcome of the oil firms' production activities.

This gave rise to rhetoric question, asking if ecological marketing practice of the oil firms has significantly reduced the trend of agricultural economic frustration in oil-bearing communities in Niger Delta. in a bid to respond to this, Okoh (2009), relates that pollution of farmlands, rivers, and the ozone layers with oil spillage substances and gas flaring activities has not only done a great deal of damage to the ecological system by the oil multinational companies but terribly destroy and frustrate the socio-economic wellbeing of the host community. Uba (2002), adds, also that an un-protected ecological environment is an unsustainable ecological system where nothing good can strive successfully. This implies that it is economically expensive to the locals in oil-bearing community to survive the oil pollution impact as also considered expensive for oil firms to pay for damages. For this and similar reasons, Perreault and Mccarthy (1999), puts that it is better for a firm to think it less expensive to do what is socially right and cost effective at a time, than to pay more-to fix a problem that is led by pressure and violence actions as considered destructive, harmful, and expensive to the firm.

To a large extent, this indicates that oil firms in Niger Delta are expected to employ more responsible ecological marketing programs that will enhance its sustainable recognition of the truth that the air, water and land are not gifts from our parents but a debt we owe to pay back to our children in good health by protecting, improving and sustaining the environment from harmful actions that affects their future wellbeing (Feegalo, 2005).

\section{Ecological Marketing Practice of the Oil Firms and the Prevention Agricultural Land Limitation in Oil-Bearing Communities in Niger Delta}

It is obvious that since the advent of oil firms in Niger Delta, ecological marketing activities of the oil firms have not considered natural for the economic wellbeing of the farmers and fishermen in Niger Delta due to the gross neglect of their socio-economic farming and fishing activities by the oil firms (Utukepo, 2011). The prevention of agricultural land limitation caused by oil pollution generated by oil firms has devalued large quality of fecund land scale in Niger Delta (Chukwu, 2008). The socio-economic decisions and survival prospect of the farmers and fishermen in Niger Delta were therefore, driven by the seeming weak ecological marketing decision of the oil firms. Gabriel (2017), equally observed that oil production activities have limit the available land for agriculture and cause serious economic hardship and frustration in oil-bearing communities. Tuyizere (2007) asserts that people in the oil-bearing states in Niger Delta, depends heavily on agricultural activities for their 
livelihood where fertile lands has been rendered unproductive and limited for food production.

In view of this, oil firms and the host community experience unwanted crisis for failure to consider the protection of the environment as part of its social responsibility. Perreault and McCarthy(1999), adds that "A firm cannot always wait until social crisis becomes obvious before thinking of doing something right; but should rather considered it harmful when customers react in anger and may be too late to fix the problem when the profits disappear". This indicates that irresponsible firms wait until social crisis becomes obvious before it will be too late to fix the problem. To this end, it was not out of context to understand that the level of poor ecological sustainability marketing practice in Niger Delta has resulted in unprecedented economic poverty and its resultant unemployment, associated with moral decadence and fast-growing criminal activities in the oil-bearing communities (Okoh, 2009). This is directly concern with the existing state of available limited farm space with pipelines that crisscross the farmlands, streams, creeks and villages in Niger Delta. With these pipelines, farmers could not have access to their farms land and fishermen access to fish in their rivers; thereby generating untold economic hardship and frustration in the host communities.

In addition, when the oil spills and gas flaring effects on the ecosystem is grossly neglected by oil firms for depriving farmers the opportunity to produce agricultural food, the value of ecological sustainability marketing is neglected (Utukepo, 2011). This add meaning to the view in Gabriel (2017), who suggests that oil communities in Niger Delta groan under the perennial destruction of their property and the ecosystem as caused by oil spillage and gas flaring activities, which in resulted in land limitation effects on farmers' progress. In line with this, Albert(2012), reported that Shell petroleum Development Company was not ignorance of the evidence of poor management of its pipelines, which its leakages was caused by corrosion in Bodo city area of Rivers state; as discovered against what Shell Petroleum Development Company's experts' findings shows (Nation Newspaper, August 3, 2012).

It was necessary to understand that any business that ignores its social responsibility in the society, has its social power threatened by what Keith et al (1978) called the "iron law of responsibility"; and in a long-run, firms that do not use their social power in a manner which the society consider responsible will tend to lose it (Chukwu , 2008). This implies that "Business firms must balance their concern and relationship with the environment with the view to accomplish consumers' expectations. For this reason, Kotler(1980), states that consumers and their environment are of great value, required to be protected, sustained and improved as part of the society, which their wellbeing is the major concern of the firm. Hardin (2009) suggests that, "It is convenient to penalize poor performing firms, which social responsibility practices are harmful to the environment and human health". Such irresponsible social responsibility practices of the oil multinational company is considered contradictory to the idea of modern management with the believe that pollution generating firms lacks merit of managerial foresight to understand the need to protect and sustain their natural environment (Jaysanka,2004).

However, in a reverse, the marketing activity of exploring the black gold had brought sorrows and tears to the land of Niger Delta, where their dreams died unnatural death, and their agricultural sustainable source destroyed, while economic hardship, poverty and land 
limitation has becomes their worst portion than what is even existing in the remotest part of Koma region, a primitive society in Adamawa state of Nigeria (Aakol, 2009).

Having notice this and similar irregularities in the oil firms' ecological sustainability marketing activity, Schiffman and Kanuk (2009), states that favorable attitudes of a company, encourage effective product positioning and marketing practice that stimulate discrimination and proper identification of a company's value from others - for long-term retention value that influence the future responsive of consumers' behavior. To be more exact, Sapru(2009), affirms in strong term that, I firmly believe too well that we shall not derive the full benefits of agriculture until we take to cooperative farming, for it stands to serve better for a hundred families in a village to cultivate their lands collectively and divide the income thereof, than to divide the land into a hundred portion for an exploiting capitalist firm that will destroy the land.

In view of this reality, Briggs (2007), state that the oil companies do not take in to consideration, the effects of oil pollution that are external to the company, because they suffer no negative effects on the huge profits; but the Niger Delta people to whom oil boom has being a doom and years of official neglect, epitomize by hunger, poverty and injustice traceable to regional denial of their productive land and agricultural source of sustainability. Udu(2007), asserts that marketers are often criticized for their unethical marketing practices, for manufacturing poor quality products and for their failure to protect and preserve the environment in which they operates. In line with agricultural land limitation, it will not be out of context in this study to understand that many business organizations has failed to understand that the consumer citizens have the right to their environment to enhance the quality of their life; with the right to live in a safe environment - not threatened by pollution and hazardous waste; as well as the right to be heard in a court of law by obtaining a redress on damages occasioned by the producers default.

\section{EMPIRICAL REVIEW}

The empirical review of this study presents a review related studies on ecological marketing practice of oil firms in the oil-bearing communities.

Hegbataama (2011) investigated the "Impact of Shell Petroleum Development Company's Environmental Marketing on Farmers in Delta State". Using 32 questions on a sample size of 300 literates' farmers in Delta State, data collected and analyzed with the use of Gamma test, revealed that "there is evidence of negative relationship between Shell Petroleum Development Company's environmental marketing practice, and the agricultural production of safe foodstuffs in the oil-bearing communities in Delta State". It was recommended that Shell Petroleum Development Company should be environmentally orientated to improve the economic wellbeing of farmers in Delta State.

Sauka and Oshita (2007) investigated the Impact of Oil Exploration on Economic Poverty in Rivers State. The study aim at examining the extent to which oil exploration activities of oil firms has reduced economic poverty in the oil-producing communities in Rivers State. A sample of 320 respondents was used for the study; and data generated were analyzed with the use of chi-squre statistics techniques. Results obtained revealed that the impact of AGIP Oil Company's Exploration Activities has not practically promoted the natural agricultural 
economic investment and reduction in economic poverty alongside its oil pollution in Rivers State. It was therefore, recommended that more proactive measures should be adopted by the oil firm to ensure drastic reduction in the level of economic poverty alongside reduction in oil pollution in the oil-bearing communities.

Koateh and Menele (2007) in a study of "Oil Exploration and Environmental Degradation in Bayelsa State", used 22 questions, served on 260 respondents in 12 local oil communities in Bayelsa State. Data analyzed with the use of t-test statistics revealed that "There is no significant impact created by ELF Oil Company to reduce environmental pollution impact on the sustainable economic activities of the oil-bearing communities in the State". It was recommended that ELF Oil Company should employ ethical based responsibility marketing approach in managing oil exploration and environmental degradation issues.

Using Shell Petroleum Development Company and ELF Oil Company in Niger Delta, Amadi and Nwomaji (2008) studied "Effects of Oil Production on the Economic Development of Oil-Producing Communities in Akwa-Ibom, Rivers and Delta State”. With a 26 count item questions on a survey instrument, data obtained were critically analyzed with the use of "Analysis of Variance (ANOVA), statistical techniques. Result obtained reveals that, "There is no significant difference in the negative effects of oil production and the economic development of oil-producing Communities in Akwa-Ibom, Rivers and Delta State". The oil producing firms should try to protect agricultural economic sustainable source of livelihood of the locals in the oil-bearing communities and the promote a sustainable development in the oil-bearing locality.

Vigale and Nenu (2006) carried out their studies of the Impact of multinational oil firms' oil spills management on the production of food in Rivers State. Data generated through 256 respondents and analyzed with the use of Pearson moment correlation coefficient revealed the result that, the effect of the multinational oil firms' oil-spills management on the production of food in Rivers State is connected with pipeline maintenance which was partially active enough to avoid oil spillages that will enhance effective production of food stuff in the host community. It was therefore recommended that oil firms should embark on more active approach of managing and maintaining its pipelines to avoid incessant oil spills that distort safe agricultural food production .

Odu (2007) investigated the "Effects of Oil Pollution on Agricultural Production in Cross Rivers State". Response generated from a sample size of 300 respondents drawn from eight oil-bearing communities was analyzed using chi-squire statistics. Result obtained revealed that critical evidence shows that "Lack of adequate sustainable quality oil production facilities resulting in oil pollution frustrates fruitful agricultural production and other related socio-economic activities in the oil-producing communities". It was recommended that Shell Petroleum Development Company should improve on its oil production facilities to avoid oil pollution and boost agricultural production and its related socio-economic activities in the oil-producing communities.

Omonona (2001) used a Tobit regression analysis format to analyze the "Causes and Effects of Socio-economic Poverty in Oil-producing States of Niger Delta". Results obtained revealed that a unit decrease in farm income, farm size and farm extension services increased the likelihood of poverty caused by oil pollution in the oil-producing communities in Lagos State. This study becomes relevance to the present study based on the agricultural 
relationship with farm income, farm size and farm extension services that increased the likelihood of poverty in Oil-bearing States of Niger Delta.

Mohammed (2008) studied "the State and the Society's Economy in Niger Delta". The data analyzed with the use of t-test statistics identified significant evidence that "the state and the society cannot survive without a virile socio-economic development if, the oil companies are not forced to be responsible in the avoidance of oil spillage in Niger Delta". It was therefore, recommended that the company should carry out responsible management practice of its oil spills. The implication of this study on the recent study is that Oil Companies in Niger Delta is expected to carry out responsible societal marketing practice, which if failed to adopt, might results in severe economic failure in Niger Delta and the country at large.

Benconi (2010) in a study of “Agip Oil Company's Environmental Responsibility in Niger Delta"; using chi-square statistical technique to analyze data gathered from 320 respondents. The result reveals that, "the environmental marketing concern of the company was ineffective and harmful to the social interests and environmental wellbeing of the oil-bearing communities". It was therefore, advisable that the company should build in ethical interest based environmental responsibility. The implication of this study on the current study is that Agip Oil Company's environmental responsibility in Rivers State is require to avoid oil spillages that affects the host communities' economic wellbeing as part of the company's corporate societal marketing responsibility.

In spite of the contributions of the empirical review of this study, it is observed that the reviewed studies could not directly examine ecological marketing and issues of agricultural economic sustainability in Niger Delta; neither does the objective of the related review examines the present objective as considered empirical gap, which this study seeks to close

\section{THEORETICAL FRAMEWORK}

In this study, the ecological system theory is adopted.

\section{Ecological System Theory}

This study used ecological system theory to explain the implication of ecological ethics on the ecological system as justified in the ethical marketing perspective of ecological sustainability marketing activities of a firm. In harmony with this, ecological sustainability marketing practice seeks to consider the satisfaction of consumers' needs and wants for environmental protection, sustainability, preservation and improvement; as well as their longterm interests alongside the sustainability of the ecological, social and economic source of the consumer citizens and the society's wellbeing. In line with this, Wriote Anderson propounded the ecological system theory in 1992, as cited by Miller, Moham Recido in 2007. The theory states that the ecological system is a hybrid of complex whole, made up of sub-components, consisting of interrelated and inter-dependent set of organisms, plants, the environment and ethical factors that functions in common for the wellbeing of the inhabitants and the society (Miller, 2007).

The theory emphasizes on the assumptions that successful existence of environmental organisms, the inhabitants and the ethical factors that seek to protect them are functions of 
environmental sustainability, improvement and preservation to their wellbeing in an interrelated and interdependent ecological system for survival. Thus, it assumed that the ecological system is a dependent component of the ecological ethics system, based on which other natural and physical related systems function for their wellbeing in the society. This implies that there is an existing relationship between the ecological system and the ecological ethics based on which the natural agricultural economic values of the environment can be sustained and achieved. The proactive sustainable drivers of the ecological system theory therefore, anchors on the ecological marketing practice of improving and preserving the environmental wellbeing of the consumers and the society in a more ethically responsible manner.

On this note, the ecological system theory is known to exist on the protective efforts of the ecological ethics theory based on which the ethical marketing perspective of ecological marketing determines the ethical dimensions and sustainability of the environmental values with which the agricultural economic consideration of oil firms and other related business organizations are expected to satisfy, protect, improve and sustain for the wellbeing of both living and none living things in the environment with human concern or feelings.

On this note, ecological system theory is use to describe the relationship between ecosystem and the ecological sustainability marketing activities that deal with the agricultural economic values and its socio-economic variables as inevitable considerations in an oil company's production activities. These are the health and economic of the flora and fauna that anchors on the marketing activities of natural resources that sustain them in the environment.

Having understood that the ecological system theory does not have its self accomplishment in isolation of ecological ethics in the practice of sustainable ecological marketing; Wriote Anderson views the ecological system theory as ethically oriented system theory based on which the pivot or axis of all environmental related marketing practice rotates. This attempts to explain that ecological marketing is an aspect of environmental marketing based on which the value of the flora and fauna are given a sustainable, ethical marketing attention during and after the production activities of business firms. In this light, the various parts that make up the ecological system like the water, land, air, fish, aquatic organisms, animals, plants and waste products, including others are interrelated, and interdependent factors or activities of one of part will affect the function of other parts. Thus, the survival of each part interrelates and depends upon the survival of the other parts of the system. Without a doubt, the operational activities and existence of the ecosystem is guided by the conventional environmental marketing ethical tenets that emphasized on creation of values that are capable of improving, preserving, sustaining, protecting and satisfying the interests and wellbeing of living and none living things in the environment. This forms a coherent function of the system that leads to the achievement of a set of goals which the set objective of ecological marketing practice of oil firms in Niger Delta is one.

To be more analytical, the oil multinational firms and other socio-economic institutions are parts of the large ecological system that depend upon the natural environment for their source of energy, material resource, waste disposal and other relevant sources. On this note, the theory implies that environmental marketing practice considers the implication of land value and the related defects of oil pollution on the ecological system. Ecological sustainability marketing looks at the variables of that affect the socio-economic system negatively, and the environmental marketing factors that requires special attention to ensure effective 
environmental protection, sustainability and preservation for the economic good of the consumer citizens and the society's wellbeing.

On the other hand, the ecological system is view as the composition of living things that requires special attention of the oil firms to protect, preserve, improve and sustain their values in a greener form in the environment. This will enable an individual to see the "earthenvironment' as the main system (called the society), that consist of an integration of social, economic and ecological sub-systems that is driven by environmental marketing activities. These set of activities integrate the functional value of living things and ecological marketing of economic resources for the wellbeing of the consumers. For this reason, Norahaus (2011) described the earth as a complex web of socio-economic and ecological factors, called system; consisting of living and non-living things, as well as the socio-economic factors functioning together for the wellbeing and interests of the society and its inhabitants. No wonder, Grace and Cohen (2011) proposes that business comprise people that processes views which are humanistic, social, economical and natural in nature; and that a deteriorating environment and planet is of no relevance in the sustainability of human life and living organisms, let alone the survival of an unethical business organization. In order to add meaning to Grace and Cohen's view, Kotler(1980) demands that consumers and their ecological environment are of great value, and they are needed to be satisfied, protected, sustained and improved as part of the society, which their environmental wellbeing is the major concern of the firm.

\section{METHODOLOGY}

The descriptive survey method of co-relational research design was adopted in this study to provide detail investigation of the procedure used to establish the relationship between environmental marketing practice and oil pollution hazard. The study used the descriptive mean score statistics and simple percentage test method for analysis of data obtain for the study. A set of questionnaire containing 20 item questions was structured and administered on 400 respondents drawn from the oil bearing communities. A modified 4-point Likert scale format cited in (Uzuaguru, 2002), was used in designing questionnaire needed to generate data for computation of the mean score statistics and simple percentage test. The study was carried out in Rivers State where respondents were randomly drawn from the oil-bearing communities. The population of this study was 7,303,900 persons (See Nigeria National Population Commission Census Web-site, projected population). A sample size of 400 persons was obtained for the study, using Taro Yamene's sample size techniques at 0.5 percent level of significant cited in Ani (2012). Purposive sampling technique was adopted, using a simple proportional percentage approach to ensure adequate representation and distribution of the questionnaire among the different strata of the population. The primary source of data was used with a structured questionnaire to elicit relevant responses from the 400 respondents. With the aid of five research assistants, out of the four hundred (400) questionnaires administered, only three hundred and sixty eight (368) copies being $92 \%$ was returned successfully, while thirty two (32) copies being $8 \%$ was not returned. The variables investigated in this study were operationalized, using "Environmental Marketing Practice and Oil Pollution Hazard" to measure the impact of the oil firms' environmental marketing practice on the reduction of oil pollution hazard with special preference to land pollution. The validation of the research instrument was confirmed by three research experts from university of Port Harcourt (two from marketing department and one from measurement and evaluation department), whose observations, modifications, views, suggestions and 
recommendations of the instrument confirmed its face and content validities. The reliability of the instrument with the use of 185 copies of a structured questionnaire administered; shows the computed reliability test result of $\mathrm{R}=.83$. This indicated considerable evident of reliability in the relationship between the two set of reliability test of the instrument.

\section{RESULTS AND DISCUSSION}

Out of the 400 questionnaires served, only 368 copies were useful and successfully collected for analysis to determine the extent of which oil firms' environmental marketing practice in oil-bearing communities improves the economic wellbeing of the natives from oil pollution hazards in Niger Delta. The mean (X) score test approach, simple percentage test method, and the $\mathrm{Z}$ - score were used for the analysis of data obtained. Interpretation of results obtained as answers to the research questions was done with the use of the following benchmarks: 1.00 - 1.49(10\%-29\%) stands for very low extent, 1.50-2.49(30\%-49\%) shows low extent, 2.50 - 3.49(50\%-69\%) stands for moderate extent, and 3.50 and above (70\%$100 \%)$ indicates high extent were employed in the study. The data generated for the study are therefore presented, analyzed and interpreted in the follows order:

\section{Number of Questionnaires Distributed.}

The total numbers of questionnaire that was distributed and returned.

Table 1: Total Number of Questionnaire Distributed and Returned

\begin{tabular}{|r|l|l|l|}
\hline $\begin{array}{l}\text { Categories of } \\
\text { Respondents }\end{array}$ & $\begin{array}{l}\text { Number } \\
\text { Distributed }\end{array}$ & $\begin{array}{l}\text { Number } \\
\text { Returned }\end{array}$ & $\begin{array}{l}\text { Number } \\
\text { Not Returned }\end{array}$ \\
\hline Males & $162(40 \%)$ & $148(37 \%)$ & $14(3 \%)$ \\
\hline Females & $238(60 \%)$ & $220(55 \%)$ & $18(5 \%)$ \\
\hline Total & $\mathbf{4 0 0}(\mathbf{1 0 0 \%})$ & $\mathbf{3 6 8}(\mathbf{9 2 \%})$ & $\mathbf{3 2}(\mathbf{8 \%})$ \\
\hline
\end{tabular}

Source: Field Survey Data 2021

\section{Social Demographic Data of Respondents.}

Social demographic information concerning respondents used for this study is presented on table 2 and 3 below. 
British Journal of Management and Marketing Studies

ISSN: 2689-5072

Volume 4, Issue 4, 2021 (pp. 99-128)

www.abjournals.org

Table 2: Distributions of Respondents by Age

\begin{tabular}{|clc|}
\hline Age Bracket & Frequency & Percentage \\
\hline $18-25$ & 63 & $16 \%$ \\
$26-35$ & 132 & $33 \%$ \\
$36-45$ & 120 & $30 \%$ \\
$46-55$ & 85 & $21 \%$ \\
Total: & 400 & $100 \%$ \\
\hline
\end{tabular}

Source: Survey Data 2021

The table above shows the analysis of the various age brackets within the age bracket of 18$25,26-35,36-45,36-45$ and $46-55$; which have the frequency distribution values of $63(16 \%), 132(33 \%), 1120(30 \%)$ and $85(21 \%)$ respectively; in confirmation of 400 copies of questionnaire administered at $100 \%$ distribution rate to the respondents.

\section{Distribution of Questionnaire by Gender Respondents' Categories}

The analysis of how copies of questionnaires were distributed to the different categories of respondents considered for the study.

Table 3: Distribution of Questionnaire by Gender to Selected Categories of Respondents

\begin{tabular}{|c|c|c|c|c|c|}
\hline $\begin{array}{l}\text { Respondents } \\
\text { Categories }\end{array}$ & Traditional Rulers & Women Leaders & Youth Leaders & Church Leader & Total \\
\hline Males & $66(16.5 \%)$ & $0(0 \%)$ & $67(16.7 \%)$ & $67(16.7 \%)$ & $200(50 \%)$ \\
\hline Female & $0(0 \%)$ & $66(16.5 \%)$ & $67(16.7 \%)$ & $67(16.7 \%)$ & $200(50 \%)$ \\
\hline Total & $80(20 \%)$ & $80(20 \%)$ & $80(20 \%)$ & $80(20 \%)$ & $400(100 \%)$ \\
\hline
\end{tabular}

Source: Field Survey Data 2021

The table above shows how the questionnaires were distributed to male and female respondents in the categories of gender for traditional rulers 66(16.5\%), women leaders $66(16.5 \%)$, youth leaders $67(16.7 \%)$, and church leaders $67(16.7 \%)$ respectively; to confirm a total distribution of $400(100 \%)$ questionnaires distributed. 
Table 4: To what extent does the ecological marketing practice of the oil firms, reduced the trend of agricultural economic poverty in the oil-bearing communities in Niger Delta? $(n=368)$

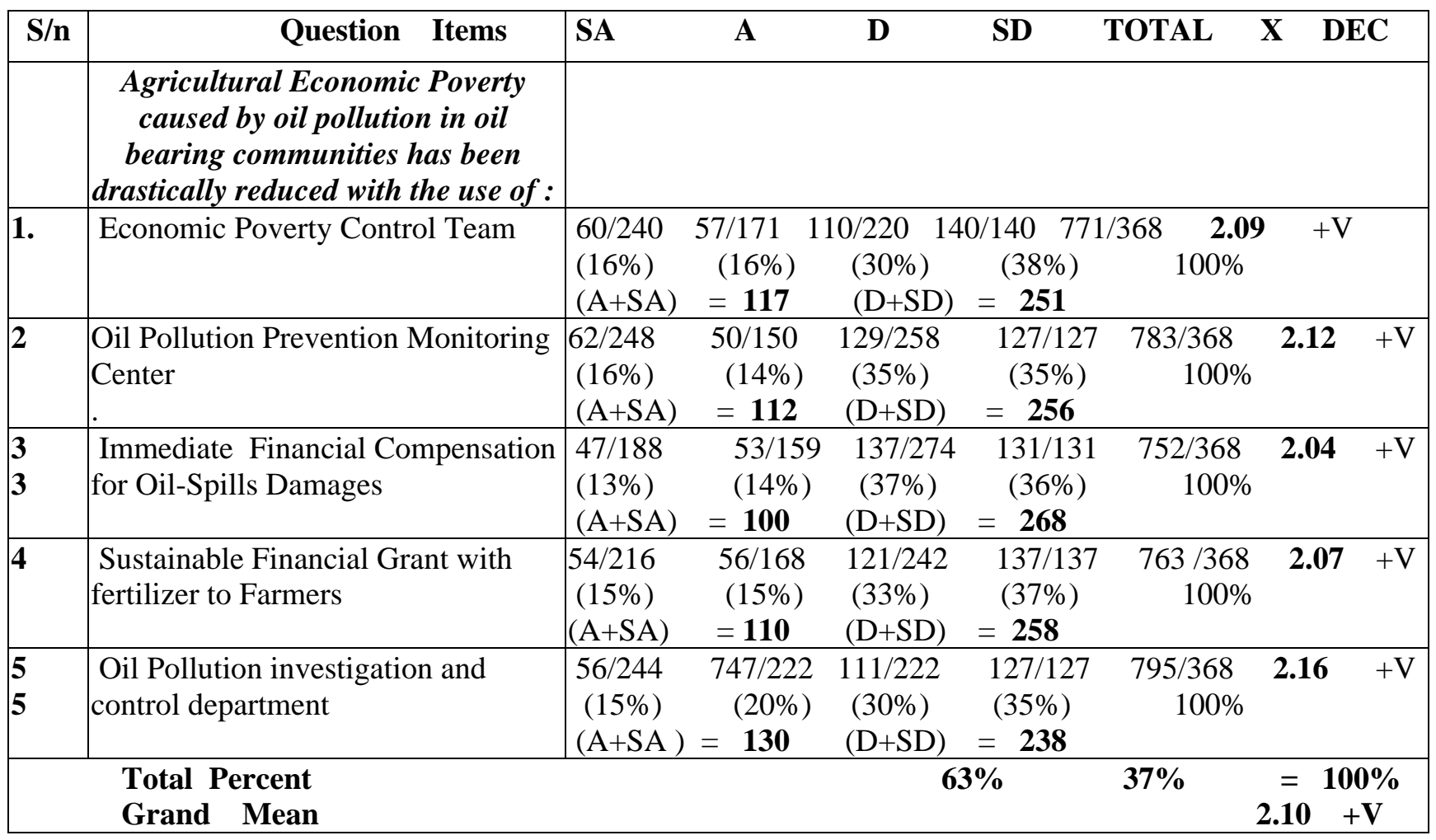

Source: Field Survey Data 2021.

Based on the benchmark used in the study, and the descriptive content details of the questions shown on table 4 above, the high percentage value of $63 \%$ agreed response was in favor of the total grand mean value of $\mathbf{2 . 1 0}$, which fall within bench mark rating scale of 1.50-2.49(30\%-49\%), which descriptively indicates that "the ecological marketing practice of the oil firms has to a low extent, reduced the trend of agricultural economic poverty in the oil-bearing communities in Niger Delta".

Conventionally, this implies that the ecological marketing activity of the oil firms was low enough to reduce the level of agricultural economic poverty in the oil-bearing communities in Niger Delta. 
Table 5: To what extent does the ecological marketing practice of the oil firms, reduced the trend of agricultural market failure in oil-bearing communities in Niger Delta? $(n=$ 368).

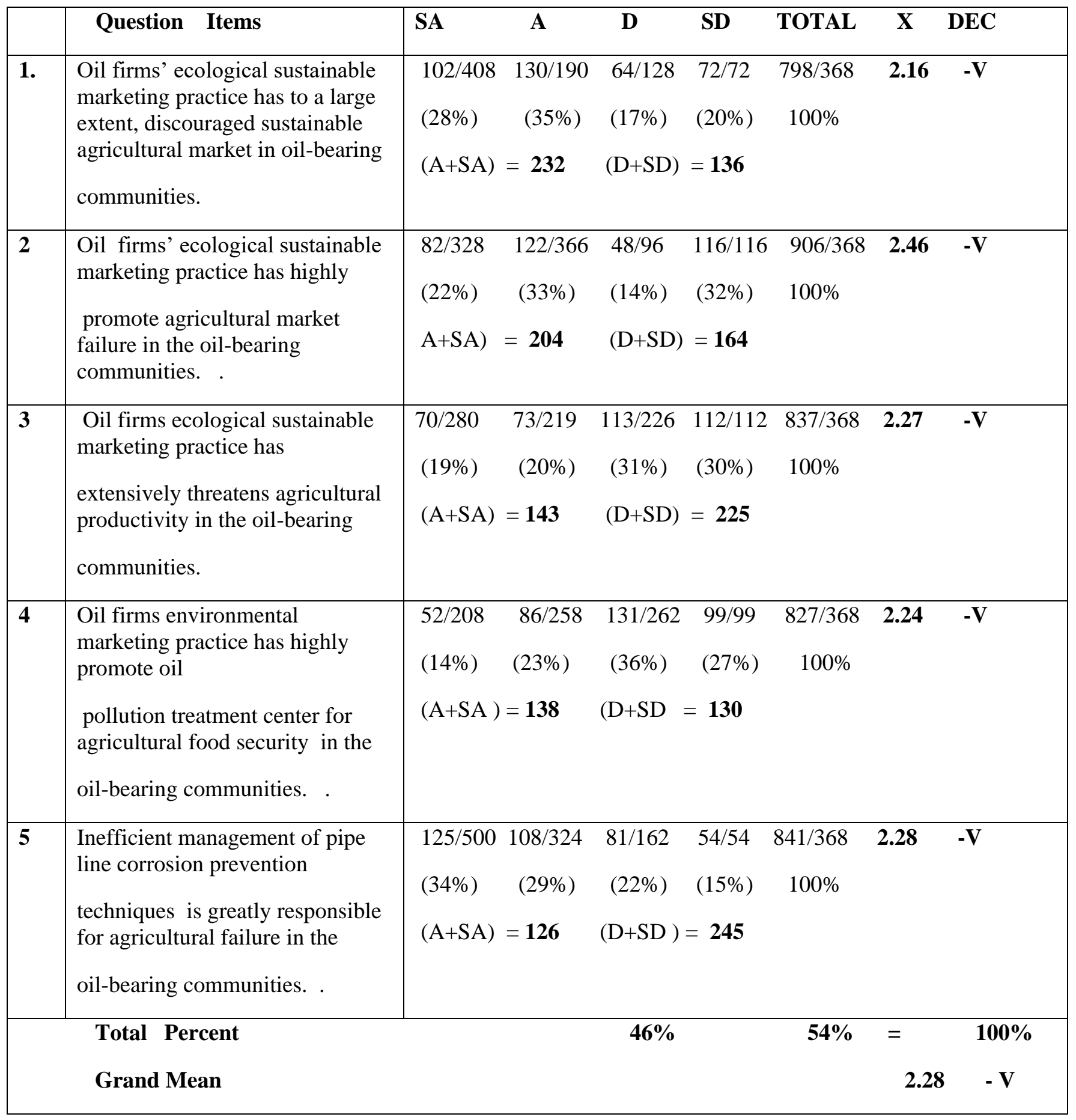

Source: Field Survey Data 2021 
Based on the benchmark used in the study, and the descriptive content details of the questions shown on table 5 above, the high percentage value of $54 \%$ agreed response was in favor of the total grand mean value of $\mathbf{2 . 2 8}$, which fall within bench mark rating scale of 1.50-2.49(30\%-49\%), which descriptively indicates that "the ecological marketing practice of the oil firms has to a low extent, reduced the trend of agricultural market failure in oilbearing communities in Niger Delta" Conventionally, this implies that the ecological marketing activity of the oil firms was low enough to reduce the level of agricultural market failure in the oil-bearing communities in Niger Delta.

Table 6: To what extent does the ecological marketing practice of the oil firms, prevents agricultural economic frustration in oil-bearing communities in Niger Delta? $(\mathbf{n}=368)$.

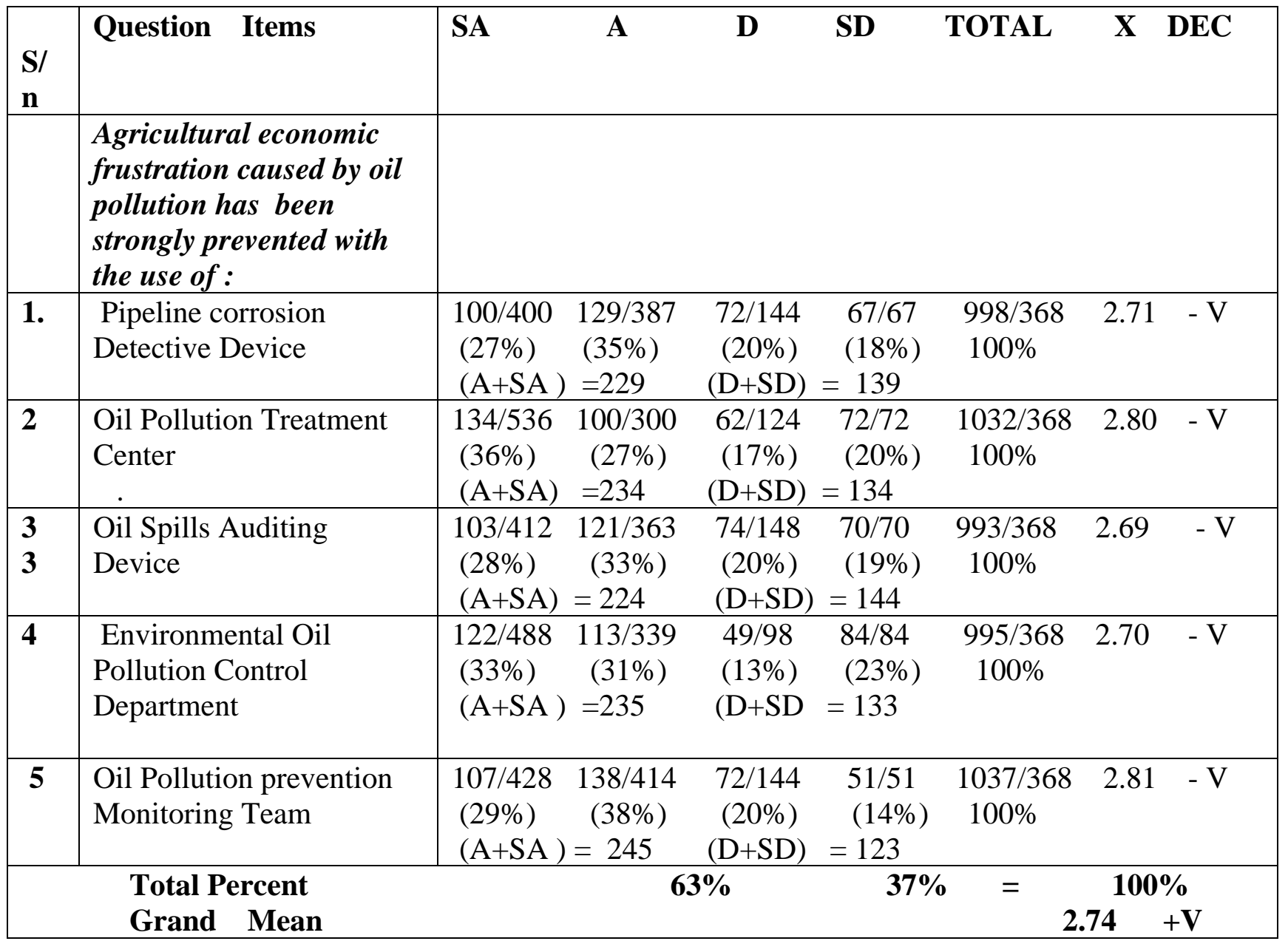

Based on the benchmark used in the study, and the descriptive content details of the questions shown on table 6 above, the high percentage value of $63 \%$ agreed response was in favor of the total grand mean value of $\mathbf{2 . 7 4}$ that fall within bench mark rating scale of $\mathbf{2 . 5 0}$ 3.49(50\%-69\%); which descriptively indicates that "the ecological marketing practice of the oil firms has to a low extent prevents agricultural economic frustration in oil-bearing 
communities in Niger Delta". Conventionally, this implies that the ecological marketing activity of the oil firms was low enough to reduce the level of agricultural economic frustration in the oil-bearing communities in Niger Delta.

TABLE 7: To what extent does the ecological marketing activities of the oil firms, prevents agricultural land limitation in oil-bearing communities in Niger Delta?

\begin{tabular}{|c|c|c|c|c|c|c|c|c|}
\hline & Question Items & SA & $\mathbf{A}$ & $\mathbf{D}$ & SD & TOTAL & $\mathbf{X}$ & DEC \\
\hline 1. & $\begin{array}{l}\text { Oil-firms ecological } \\
\text { sustainability marketing } \\
\text { practice has extensively } \\
\text { increase agricultural land } \\
\text { destruction in oil-bearing } \\
\text { communities } \\
\text { in Niger Delta. }\end{array}$ & $\begin{array}{l}102 / 408 \\
(28 \%) \\
(\mathrm{A}+\mathrm{SA}\end{array}$ & $\begin{array}{l}130 / 190 \\
(35 \%) \\
=232\end{array}$ & $\begin{array}{l}64 / 128 \\
(17 \%) \\
(D+S D)\end{array}$ & $\begin{array}{l}72 / 72 \\
(20 \%) \\
=136\end{array}$ & $\begin{array}{l}798 / 368 \\
100 \%\end{array}$ & 2.16 & $-\mathrm{V}$ \\
\hline 2 & $\begin{array}{l}\text { Oil firms' unwillingness to } \\
\text { avoid incessant oil pollution } \\
\text { on the } \\
\text { limited agricultural land } \\
\text { space is highly driven by the } \\
\text { firms' selfish } \\
\text { profits making intention. }\end{array}$ & $\begin{array}{l}82 / 328 \\
(22 \%) \\
(\mathrm{A}+\mathrm{SA}\end{array}$ & $\begin{array}{c}122 / 366 \\
(33 \%) \\
=204\end{array}$ & $\begin{array}{l}48 / 96 \\
(14 \%) \\
(\mathrm{D}+\mathrm{SD})\end{array}$ & $\begin{array}{c}116 / 116 \\
(32 \%) \\
=164\end{array}$ & $\begin{array}{l}906 / 368 \\
100 \%\end{array}$ & 2.46 & $-\mathrm{V}$ \\
\hline 3 & $\begin{array}{l}\text { The poor maintenance } \\
\text { culture of the oil firms has } \\
\text { on a large scale } \\
\text { reduced pipe line corrosion } \\
\text { to ensure quality land value } \\
\text { improvement. }\end{array}$ & $\begin{array}{l}70 / 280 \\
(19 \%) \\
(\mathrm{A}+\mathrm{SA}\end{array}$ & $\begin{array}{c}73 / 219 \\
(20 \%) \\
=143\end{array}$ & $\begin{array}{l}113 / 226 \\
(31 \%) \\
(\mathrm{D}+\mathrm{SD})\end{array}$ & $\begin{array}{l}112 / 112 \\
(30 \%) \\
=225\end{array}$ & $\begin{array}{c}837 / 368 \\
100 \%\end{array}$ & 2.27 & $-\mathrm{V}$ \\
\hline 4 & $\begin{array}{l}\text { The oil firms' ecological } \\
\text { sustainability marketing } \\
\text { practice, has on } \\
\text { a very low scale prevents } \\
\text { agricultural land limitation } \\
\text { in the } \\
\text { oil-bearing communities. . }\end{array}$ & $\begin{array}{l}52 / 208 \\
(14 \%) \\
(\mathrm{A}+\mathrm{SA}\end{array}$ & $\begin{aligned} & 86 / 258 \\
& (23 \%) \\
= & 138\end{aligned}$ & $\begin{array}{l}131 / 262 \\
(36 \%) \\
(\mathrm{D}+\mathrm{SD}\end{array}$ & $\begin{array}{c}99 / 99 \\
(27 \%) \\
=130\end{array}$ & $\begin{array}{c}827 / 368 \\
100 \%\end{array}$ & 2.24 & $-\mathrm{V}$ \\
\hline 5 & $\begin{array}{l}\text { Incessant oil spills that } \\
\text { causes agricultural land } \\
\text { limitation in the } \\
\text { oil-bearing communities has } \\
\text { been given proactive ethical } \\
\text { marketing } \\
\text { attention in a responsible } \\
\text { manner by oil firms. . . }\end{array}$ & $\begin{array}{l}77 / 308 \\
(21 \%) \\
(\mathrm{A}+\mathrm{SA}\end{array}$ & $\begin{array}{c}46 / 138 \\
(13 \%) \\
=123\end{array}$ & $\begin{array}{c}137 / 274 \\
(37 \%) \\
(\mathrm{D}+\mathrm{SD})\end{array}$ & $\begin{aligned} & 108 / 108 \\
& (29 \%) \\
= & 245\end{aligned}$ & $\begin{array}{c}841 / 368 \\
100 \%\end{array}$ & 2.28 & $-\mathrm{V}$ \\
\hline & $\begin{array}{l}\text { Total Percent } \\
\text { Grand Mean }\end{array}$ & & \multicolumn{2}{|c|}{$46 \%$} & $54 \%$ & $\begin{array}{l}= \\
2.28\end{array}$ & \multicolumn{2}{|c|}{$\begin{aligned} 100 \% \\
8 \quad-V\end{aligned}$} \\
\hline
\end{tabular}

Source: Field Survey Data 2021. 
Based on the benchmark used in the study, and the descriptive content details of the questions shown on table 7 above, the high percentage value of $54 \%$ disagreed response was in favor of the total grand mean value of $\mathbf{2 . 2 8}$, that fall within bench mark rating scale of 1.50-2.49(30\%-49\%); which descriptively indicates that "the ecological marketing activities of the oil firms, has to a low extent prevented agricultural land limitation in oil-bearing communities in Niger Delta. Conventionally, this implies that the ecological sustainability marketing activity of the oil firms was low enough to reduce the level of agricultural land limitation in the oil-bearing communities in Niger Delta.

\section{TEST OF THE HYPOTHESES}

\section{Assumptions of the employed Z-test model for the hypotheses}

1. The oil firms under this study is arguably observed that the firms are engaged in environmental marketing practices that causes a seeming uncontrolled oil pollution hazards in Niger Delta without considering the negative impact on the agricultural economic wellbeing of the natives in the oil-bearing communities. The issue is to ascertain if, the oil firms' environmental marketing practice have presently, created some significant improvement on the agricultural economic wellbeing of the natives in oil-bearing communities.

2. A one-tailed test alternative is the accepted alternative hypothesis only when the null hypothesis is rejected.

3. A Z-test of the hypothesis would be used with one critical value of 0.2088 derived from $5 \%$ level of significance as obtained from the critical table value of $\mathrm{Z}$ scores.

4. The question items were designed in a modernized 4 point Likert scale format, and only strongly agree and agree were used as positive responses, while strongly disagree and disagree were considered as negative responses (Ani, 2012).

5. If the calculated $\mathrm{Z}$ score is greater than the tabulated value, then the null hypothesis would be rejected and the alternate hypothesis is accepted (Mason, Lind and Marchal, 1999).

6. Using the $\mathrm{Z}$ score formula: $\mathrm{Z}_{\mathrm{c}}=\mathrm{P}-\mathrm{P}_{\mathrm{O}}$

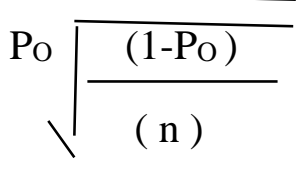

Where:

$\mathrm{P}=$ Percentage of positive responses

Po $=$ Probability of rejecting the null hypotheses

$\mathrm{n}=$ Sample size 


\section{Test of Hypothesis 1:}

Ho1: The ecological sustainability marketing activities of the oil firms has not significantly prevented agricultural economic poverty in the oil-bearing communities in Niger Delta.

$\mathbf{H}_{\mathrm{A} 1}$ : The ecological sustainability marketing activities of the oil firms has significantly prevented agricultural economic poverty in the oil-bearing communities in Niger Delta.

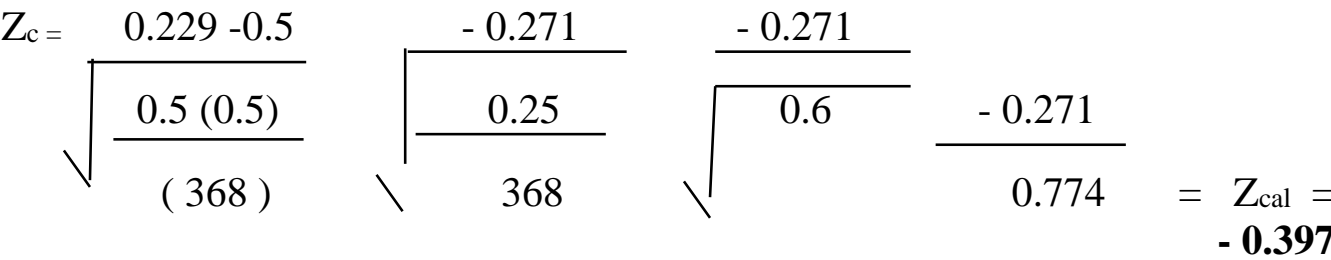

$$
\begin{aligned}
& \mathrm{Z}_{\mathrm{tab}}= \\
& 0.2088
\end{aligned}
$$

Since $Z_{c a l}(-0.397)$ is less than $Z_{\text {tab }}(0.2088)$; the null hypothesis $\left(\mathrm{Ho}_{0}\right)$ is Retained, and the alternate hypothesis $\left(\mathrm{H}_{\mathrm{A}}\right)$ is Rejected. Therefore, it is confirmed that the ecological sustainability marketing activities of the oil firms has not significantly prevented agricultural economic poverty in the oil-bearing communities in Niger Delta.

\section{Test of Hypothesis 2:}

Ho2: $\quad$ The ecological sustainability marketing activities of the oil firms, has not significantly prevented agricultural market failure in oil-bearing communities in Niger Delta

$\mathbf{H}_{\mathbf{A 2}}$ The ecological sustainability marketing activities of the oil firms, has significantly prevented agricultural market failure in oil-bearing communities in Niger Delta.

$$
\mathrm{Z}_{\mathrm{c}}=\frac{0.317-0.5}{0.5 \sqrt{\frac{(0.5)}{(368)}}}
$$
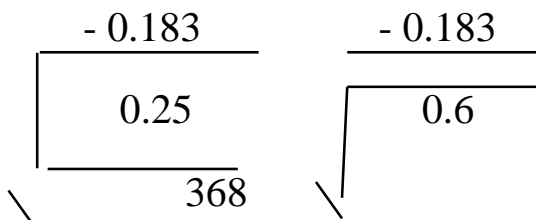

$\frac{-0.183}{0.774}=\underset{\substack{\text { cal } \\ \mathbf{0 . 2 3 6}}}{Z^{2}}$

Since $Z_{c a l}(-0.236)$ is less than $Z_{\text {tab }}(0.2088)$; the null hypothesis $\left(\mathrm{Ho}_{0}\right)$ is Retained, and the alternate hypothesis $\left(\mathrm{H}_{\mathrm{A}}\right)$ is Rejected. Therefore, it is confirmed that the ecological sustainability marketing activities of the oil firms has not significantly prevented agricultural market failure in oil-bearing communities in Niger Delta. 


\section{Test of Hypothesis 3:}

Ho3: The ecological sustainability marketing activities of the oil firms, has not significantly

prevented agricultural economic frustration in oil-bearing communities in Niger Delta.

$\mathbf{H}_{\mathbf{A 3}}$ The ecological sustainability marketing activities of the oil firms, has significantly prevented agricultural economic frustration in oil-bearing communities in Niger Delta.

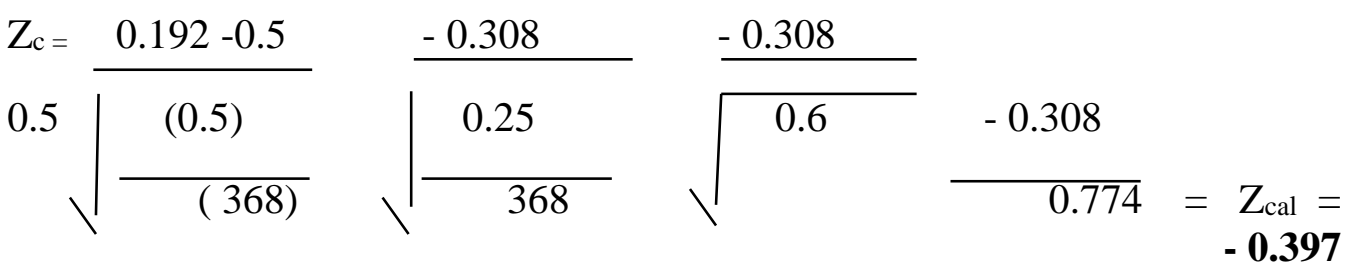

$$
\begin{aligned}
& \mathrm{Z}_{\mathrm{tab}}=
\end{aligned}
$$

Since $Z_{c a l}(-0.397)$ is less than $Z_{\text {tab }}(0.2088)$; the null hypothesis $(\mathrm{Ho})$ is Retained, and the alternate hypothesis $\left(\mathrm{H}_{\mathrm{A}}\right)$ is Rejected. Therefore, it is confirmed that the ecological sustainability marketing activities of the oil firms, has not significantly prevented agricultural economic frustration in oil-bearing communities in Niger Delta.

\section{Test of Hypothesis 4:}

Ho4: The ecological sustainability marketing activities of the oil firms, has not significantly agricultural land limitation in oil-bearing communities in Niger Delta.

$\mathbf{H}_{\mathrm{A} 4}$ The ecological sustainability marketing activities of the oil firms, has significantly prevented agricultural land limitation in oil-bearing communities in Niger Delta.

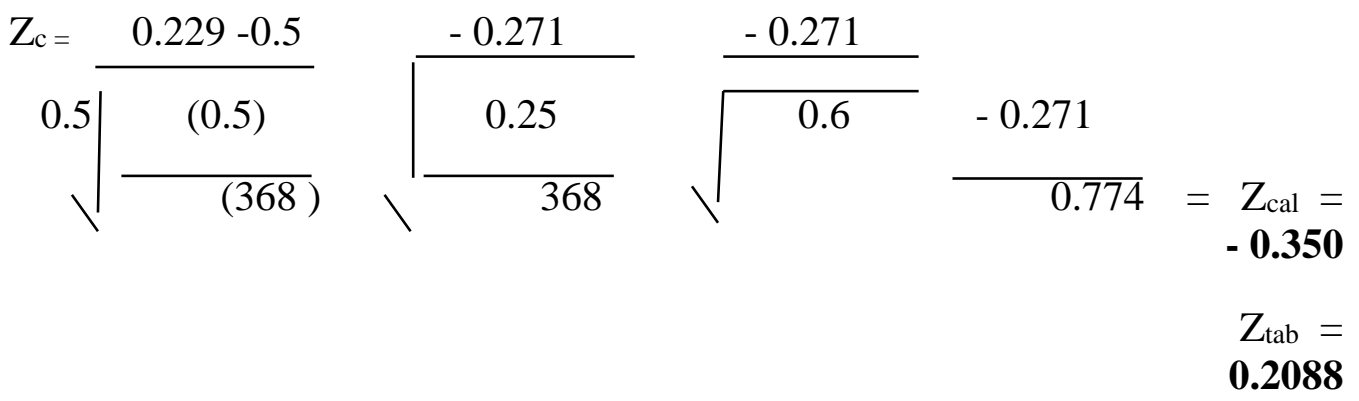


Since $\mathrm{Z}_{\mathrm{cal}}(-0.350)$ is less than $\mathrm{Z}_{\mathrm{tab}}(0.2088)$; the null hypothesis $(\mathrm{Ho})$ is Retained, and the alternate hypothesis $\left(\mathrm{H}_{\mathrm{A}}\right)$ is Rejected. Therefore, it is confirmed that the ecological sustainability marketing activities of the oil firms, has not significantly prevented agricultural land limitation in oil-bearing communities in Niger Delta.

\section{DISCUSSION}

Based on the computed grand mean result of $\mathbf{2 . 1 0}$ in table 4, 2.28 in table 5, 2.74 in table 6; and 2.28 in table 7; and its related supportive total percentage result of $63 \%$ in table $4,54 \%$ in table 5, 63\% in table 6 , and 54\% in table 7 respectively, reveals that "The oil firms' ecological sustainability marketing activities has to a low extent prevented agricultural economic poverty, agricultural market failure, agricultural economic frustration, and agricultural land limitation caused by oil pollution in the oil-bearing communities of Niger Delta. To justify this, the result was also, separately confirmed in the review of related literature which hinged on empirical findings and/or observations deduced from the studies in Osabie (2007); Odu (2007); Koateh and Menele (2007); Amadi and Nwomaji (2008); Aakol (2009); Perreault and Utukepo, 2011); and Schiffman and Kanuk (2009), who confirmed the content validity of the result in the view that: "The ecological sustainability marketing activities of the oil firms to sustain, protecting, improving and preserving the natural land value has not only been low enough to prevent agricultural market failure, agricultural food poisoning, agricultural economic frustration, economic poverty and agricultural land limitation caused by oil pollution hazards; but the firms' ecological marketing activities was also found to lack proactive improvement value to sustain the socio-economic wellbeing of the natives in oil-bearing communities in Niger Delta. On a large scale, the theoretical solutions obtained as answers to the research questions deduced from the review of related literature, agree with the scientific test results of the hypothesized variables in the study.

\section{CONCLUSION}

This study to examine the extent to which the ecological sustainability marketing activities of the oil firms: Shell BP, Agip Oil Company, and Elf Oil Company have improved the quality of agricultural economic wellbeing of the oil-bearing communities in Niger Delta. Based on the analysis of the data collected, analyzed and interpreted, the study reveals that "The extent to which oil firms' ecological sustainability marketing activities of the oil firms have improved the quality of agricultural economic wellbeing in oil-bearing communities has been low in Niger Delta. This leads to the conclusion that the oil firms' firms' ecological sustainability marketing activities was not only poisonous or harmful to the socio-economic wellbeing of the host oil-bearing communities, but also capable of causing lethal or deadly impact which its Societal Marketing Based Ethical Value' to sustain, protect, improve and preserve the natural agricultural land value is neglected in the prevention of agricultural market failure, agricultural food poisoning, economic poverty, agricultural economic frustration, and agricultural land limitation caused by oil pollution in the oil-bearing communities in Niger Delta". 


\section{RECOMMENDATIONS}

Based on the findings obtained from this study, the following recommendations were deduced.

1. Oil firms should formulate "Land Protection and Sustainability Policy (LANPROSUP)," and apply it to "Land-Care Ecological Sustainability Marketing Decisions" of the oil firms to avoid agricultural market failure. This will help to sustain the economic wellbeing of the natives from land related oil pollution that will enlarge the scope of agricultural production and market.

2. Oil firms should also establish "Environmental Protection and Responsibility Marketing Unit" (EPARMU), in the marketing department of the oil firms to oversee all issues concerning environmental food poisoning caused by oil pollution in the host community. This will help the oil firms to manage their environmental oil pollution related protection issues.

3. Oil firms should also build "Environmental Solution Monitoring and Treatment Centers (ESMTC)" in each oil-producing areas to oversee the problem of socioeconomic poverty caused by oil pollution as connected to poor production of agricultural food in the oil-bearing communities in Niger Delta. This will help to reduce the high rate of economic poverty, associated with recklessness, and financial frustrations caused by oil pollution among farmers, fishermen and youths in the oilbearing communities in Niger Delta.

4. Oil firms should also formulate "Host Community Land Preservation Development Policy (HOSTCOM-LPDP)" alongside the appointed team of expert environmental marketing professionals to work with a set of representatives of the host community to oversee issues on land preservation and protection control mechanism. This will help to enable the oil firms adopt proactive improvement measures on land security in the host community.

\section{REFERENCES}

Aakol, K. G. (2009). Niger-Delta Sustainable Development as a Strategy for Conflict Prevention: The case of Environmental Pollution in Niger Delta. Vico Publishers. Akpan, F.(2005). Ethnic Militancy and the Nigerian State, Journal of International Politics and Development Studies, 2(2) 20-27.

Ani, I. P. (2012). Resarch Methodology for Social and Management Sciences. Kenton Publishers.

Amadi, Y. N. and Nwomaji, B. S. (2008). SPDC and ELF Oil Companies: The Position of Indigenes in Niger Delta. Nigerian journal of corporate management, 2(3); 60-69.

Asakitikpi, E. A. and Oyelavan, A. P. (2006). Oil Extraction and the Socio-cultural Impact on People of the Niger Delta, A paper presented at the $4^{\text {th }}$ Annual Conference of Environmental Protection society of Nigeria.

Bomi, Z. (2010). Conflict Resolution, Identity Crisis and Development in Africa, Mattheouse Press Ltd. 
Briggs, M. P. (2007). Oil and Environmental Degradation in Niger Delta. Vol. 2. Ibadan: Ibadan University Press.

Chukwu, O.J. (2008). Environmental Management and Ecocide Activities in Niger Delta; Kenton Publishers.

Danhagu, E. (2008). The Place of Shell Petroleum Development Company in the Development of Oil- bearing Communities in Akuku- Toru Local Government Rivers State. Journal of Corporate Security 11(2); 94-108.

Ekpu, B. (2010). Environmental Pollution in the Niger Delta: An Economic Perspective, International Conference on the Nigeria State, Oil Industry and the Niger Delta, pp 131-137.

Fayifu, T. (2006). Women Environment and Food production: The Challenge of the Niger Delta, Nigerian Journal of Environment Management 2(2); 72-80.

Funiwa, F. Y. (2002). Oil for Nothing: Multinational Corporations, Environmental Destruction, Death and Impurity in the Niger Delta, Nigerian Journal of Environment Management. 3(1) 93-100.

Feegalo, B. (2005). Environmental Management and Oil Pollution Evidence in Niger Delta: The Economic Position of Farmers; Journal of Corporate Security 2(3); 84-96.

Gabriel, A. I. (2017). Ogoni Struggle Continues. Geneva and Nairobi, World Council of Chambers and all African Council of Churches Conference.

Gilbert, S. J. (2012, August 3). Oil Pollution: The Causes of environmental Crisis in Niger Delta, Nation Newspaper, p.8

Grace, A and Cohen, B. E. (2011). Oil for Nothing: Multinational Corporations and Environmental Destruction in Niger Delta, Nigeria Journal of Environmental Research 1(2); 37-42.

Hawkins, D. Best R. J. and Coney, K. A. (2001). Consumers Behaviour: Building Marketing Strategy, McGraw Hill Companies Inc.

Hicks, E.F. and Gullets, T. (1980). Management Science and Practice; McGraw Hill Companies Inc.

Hegbataama G.E. (2011). Environmental Marketing and food Security in Delta State, Nigerian Journal of Marketing Research, 2(7); 162-168.

Heig, I. P. (1999). Petroleum Industry and the Paradox of Rural Poverty in the Niger Delta Ethiope, Benin City Kenton Publshers.

Hardin, R.D.(2009). The effect of oil Pollution on Niger Delta Economy, International conference on the Niger Delta State, Oil Industry and Niger Delta PP 362-367

James and Roger, I. M. (2001). Responsibility Marketing for Industrial, Lagos: Donhan Publishers.

Jaysanka, A. A. (2004). Marketing Management and Theory. Benkaji Publishers

Kotler, P. (1980). Marketing Management, Prentice-Hall Publishers.

Kotler, P. (2000). Marketing Management, Millennium Edition New Delhi: Prentice-Hall of India.

Mohammed, J.F. (2008), The State and the Society Economy Niger Delta; Nigerian Human Security Journal 1(3); 26-36.

Koateh, E, V. and Menele, S. (2007). Multinational Oil Companies and Environmental Degradation in Bayelsa State, Nigerian Journal of Corporate Management 3(2); 43-48.

Morgan, I. and Russug, O. (2000). Where Vultures Feast: Forty Years of Shell in Niger Delta, Ibadan: Kraft Books Limited.

Miller, L. (2007). Niger Delta Crisis: The effect on Nigeria Economy, International conference on the Niger Delta state, Oil Industry and Niger Delta PP 362-367 
Obi, C. (2010). Oil of Environmental Confliction in National Nigeria Security: Reunification of the Ecology- Security Nexus for the sub-Regional Peace, Nigerian Journal of Environment Management. 1(2); 31 - 38.

Odu, C.T. I. (2007). Niger Delta Environment and Oil Production : The Hazards Involved, Journal of Management Studies, 3(3); 42-47.

Omonona, B.T. (2001). "Causes and Effects of Socio-economic Poverty in Oil-producing States of Niger Delta", International Journal of Environment Studies 11(2); 99-106.

Omuni, D. J; and Ekan, N.O. (2012). Environmental Oil Pollution and Confliction in Niger Delta: A Focus on Ecological insecurity Nigerian Journal of Environment Management. 1(2); $41-48$.

Okon, D.R.(2006). Environmental Pollution in the Niger Delta: The impact on Human Health and the Society, Paper Presented at 3rd International Conference on Petroleum Industry in Nigeria, Port Harcourt. $20^{\text {th }}$ July, 1985.

Onuoha F. C. (2008). Oil Exploitation, Environmental Degradation and Climate Change: Assessing the Vulnerability of the Niger Delta Environment to Natural Disaster. International Conference on state, oil industry and the Niger Delta, Port Harcourt: Harley Publications.

Osagbae, E. E. (2007).Managing Multiple Minority Problems in a Divided Society: The Nigerian Experience in Niger Delta, Journal of Modern African Studies 36(4); 22-28.

Osabie, A. (2007). Introduction to Marketing, Onitsha: African FEP Publishers Ltd.

Perrault, W .D. and McCarthy, E.(1999). Basic Marketing: Global Managerial Approach. $13^{\text {th }}$ Ed. Irwin McGraw-Hill.

Sapru, R. K. (2009), Administrative Theories and Management. Thought: New Delhi, PHI Learning. Private Limited.

Sugu, G. (2005, July 10). Shell Oil Spills: The Root of Oil crisis in Niger Delta, Punch, Newspaper, p.7

Sohiffman, L. G. and Kanuk, L. L. (2009).Consumers Behaviour. $9^{\text {th }}$ edition, New Hersey : Pearson Education Hall.

Sauka, J.A. and Oshita, O. (2007). Impact of Oil Exploration on Economic Poverty in Rivers State Nigerian Journal of Environmental and Economic Research, 2(1); 81-90.

Tuyizere, A. P. (2007). Women and Agricultural Development in Niger Delta. Kampula, Makarere University press.

Uba, (2002). Crisis in the Oil-producing Communities in Nigeria, Journal of human Ecology 16(3) 201- 216.

Udu, C. T. I. (2007). The Oil Industry and the Environment: The Nigerian Account, Journal of Institute of Petroleum. 58(1) 201-208.

Ukaogo, O. (2007).Poverty in Niger Delta oil-producing community, Port Harcourt: Benson and sons publishers.

Utukepo, A.C. (2011). Essentials of Environmental Issues: The World and Nigeria in Perspective, Ibadan: Daily Graphics Publications. 103.

Uzoagulu, A.E. (2002). Practical Guide to Working Research Projects in Tertiary Institutions, Enugu: John Jacob's classic publishers Ltd.

Vigale, D. and Nenu, B.Y. (2006). Impact of Oil Pollution on Food Production and Economic Poverty in Rivers State; Nigeria Journal of Environmental Research (1)2; 57-62.

Willims R. M. S. (2000). Marketing Management London: Butter-Worth Heinemann. 